\title{
The action of Metaloproteinases in the Atherosclerotic Diseases
}

\section{Ação das Metaloproteinases nas Doenças Ateroscleróticas}

Álvaro Luís Müller da Fonseca¹, Fernanda Washington de Mendonça Lima², Ricardo David Couto³

${ }^{1}$ Laboratory of Immunology, Departamento de Educação (DEDC7), Universidade do Estado da Bahia (UNEB) - Senhor do Bonfim (BA), Brasil.

${ }^{2}$ Faculdade de Farmácia da Universidade Federal da Bahia (UFBA) - Salvador (BA), Brasil.

${ }^{3}$ Laboratory of Clinic Biochemical, Faculdade de Farmácia da UFBA - Salvador (BA); Laboratório Central, Hospital Universitário Professor Edgar Santos (HUPES) - Salvador (BA), Brasil.

DOI: http://dx.doi.org/10.7322/abcshs.v39i3.654

\begin{abstract}
Cardiovascular diseases represent the main cause of morbidity and mortality in the world and are epidemic events involving the atherosclerosis and coronary artery disease in particular. There are a wide variety of factors and markers associated with the development and aggravation of these diseases, including atherosclerosis. Subclinical Atherosclerosis can be determined by serum inflammatory markers present in the atherogenic process. Such markers can take a direct or indirect indicator role on atherosclerotic cardiovascular disease. The extracellular matrix metalloproteinases are biomarkers closely related into modifying and remodeling of vascular wall and other tissues and can represent predictive value patterns to support diagnosis. This review discusses the function and types of matrix metalloproteinases and its use as an indicator of support for the diagnosis of atherosclerosis.
\end{abstract}

Keywords: ischemia; plaque, atherosclerotic; peptide hydrolases; atherosclerosis.

\section{RESUMO}

As doenças cardiovasculares compreendem a maior prevalência de morbidade e mortalidade no mundo, sendo uma epidemia da qual se destacam a aterosclerose e a doença arterial coronária. Há grande diversidade de fatores e marcadores associados ao desenvolvimento e agravo dessas doenças, incluindo a aterosclerose, que subclinicamente pode ser evidenciada pela determinação de marcadores inflamatórios séricos participantes do processo aterogênico. Tais biomarcadores são considerados medidas diretas ou indiretas de doença cardiovascular aterosclerótica. As metaloproteinases estão relacionadas com a modificação/remodelamento da parede vascular e outros tecidos, podendo representar parâmetros com valor preditivo para o apoio diagnóstico. Esta revisão aborda o mecanismo de ação e os tipos de metaloproteinases de matriz, bem como seu uso como indicador de apoio no diagnóstico da aterosclerose.

Palavras-chave: isquemia; placa aterosclerótica; peptídeo hidrolases; aterosclerose.

Received: 09/18/2013

Revised: 11/19/2013

Accepted: 03/27/2014

Corresponding author: Álvaro Luís Müller da Fonseca - Universidade do Estado da Bahia - Rodovia Lomanto Junior, BR 407, km 127 - CEP: $48970-000$ Senhor do Bonfim (BA), Brasil - E-mail: alfonseka@gmail.com

Conflict of interests: nothing to declare. 


\section{THE EXTRACELLULAR MATRIX AND THE METALLOPROTEINASES CHARACTERISTICS}

The extracellular matrix (ECM) is composed primarily of vascular collagen, elastin, glycoproteins and proteoglycans secreted especially by fibroblasts and smooth muscle cells, which, by the way, are molecules that act on cell adhesion, migration, proliferation, differentiation and morphogenesis. The metalloproteinases (MMP) and the serine proteases are enzymes that degrade and remodeling the MEC. The main histopathological changes in the aorta involve MEC compounds, thus the metalloproteinases made the hydrolysis of elastin and collagen degradation, for example ${ }^{1,2}$.

The metalloproteinases (matrixins) are endopetidases with zinc in its active site and act as zymogens that are dependent on calcium for activation after cleavage. They are activated by trypsin, plasmin, thrombin, kallikrein, elastase, cathepsin, tryptase, kinase and some other MMP. The main inhibitors are the tissue inhibitors of metalloproteinases (TIMP). The MMP degrade the ECM proteins (collagen, elastin, fibronectin, proteoglicanas), including basal membrane and proteins. They also are expressed in various cells and tissues, such as the vascular smooth muscle cells (VSMC), endothelial cells, fibroblasts, lymphocytes, macrophages and platelets. The MMP are related to the pathophysiological processes, as well as the embryonic development, organogenesis, reproduction, ovulation, apoptosis, angiogenesis, cell migration and tissue remodeling and absorption ${ }^{3,4}$.

The MMP degrade extracellular matrix proteins breaking specific peptide bonds and resulting in vascular remodeling, which consists of adaptive physiological process that occurs in the blood vessels in response to hemodynamic chronic alterations ${ }^{5}$. The interactions between the cells and the extracellular matrix are modulated by MMP, which consists of the main biological function of these proteins, i.e. join the control signals issued by the cells, running the proliferation, differentiation and cell death and then regulate the integrity and structure of ECM. Therefore, the action of MMP must be precisely regulated, because an out-of-control proteolysis contributes to abnormal development and degeneration in many pathological conditions characterized by excessive degradation, as for non-degradation of compounds of ECM ${ }^{6}$.

All MMP are secreted in a non-active form (zymogens or pro-enzymes) and are activated by other enzymes like plasmin or other metalloproteinases (for example, MMP-1, 3, 7, $9,13)$. The activities of the MMP are regulated in several levels: genic expression/transcription, synthesis of pro-enzyme, activation of zymogens, after translation and interaction with their inhibitors (TIMP). The latency as pro-MMP enzyme is sustained by interaction with the cysteine residue present in the domain of pro-peptide that has zinc in the active center (catalytic), causing the blockage of this substrate ${ }^{6}$. In addition to these processes, regulation and inhibition of MMP are made by $\alpha$-2-macroglobulina (non-specific inhibitor), among other non-specific enzymes ${ }^{2,7}$. In this way, the regulation of MMP occurs in vascular microenvironment where the TIMP, among other enzymes, controlling the activities of MMP in the tissues, whereas the $\alpha 2$-macroglobulina performs the control in plasma. There are four types of TIMP (TIMP-1, 2, 3, 4) and they inhibit MMP activity by non-covalent binding to the catalytic domain, creating high-affinity complexes. In other words, the biological process which involves the MMP is dependent on the balance between the natural inhibitors and protease. Thus, the instability of this balance results in diseases associated with uncontrolled proteolysis of the connective tissue, like chronic-degenerative and inflammatory diseases, and tumors ${ }^{8}$. The expression and increased activity of MMP can result in excessive cardiovascular remodeling and arterial atherosclerosis ${ }^{5}$.

About 20 Metalloproteinases are currently known from 24 described in the total (Table 1) and arranged into collagenases, gelatinases, stromelysins, matrilysins, membrane metalloproteinases, and others metalloproteinases, together with the subgroups of ADAM (desintegrin and metalloproteinases) and ADAMT (ADAM with polypeptide chains as thrombospondin type motif), and astacins serralysin. They have in common the following characteristics: 1) degrade extracellular matrix compounds; 2) contain the zinc ion $(\mathrm{Zn} 2+)$ in the active site; 3$)$ calcium ion $(\mathrm{Ca} 2+)$ required for stability; 4) is functional in neutral $\mathrm{pH}$; and 5) specific tissue inhibitors of matrix metalloproteinases (TIMP) make his inhibition'. The extracellular matrix acts as a barrier to cell migration and its degradation allows cell migration, alterations in the microenvironment of the extracellular matrix and on the ECM cells behaviour induce proliferation, apoptosis or morphogenesis and the modulation of activity of biologically active molecules (for example, growth factors) ${ }^{10}$.

\section{MATRIX METALLOPROTEINASE TYPES}

\section{Collagenases}

The MMP-1 (collagenase-1 or interstitial), MMP-8 (collagenase-2, neutrophilic or leucocytic) and MMP-13 (collagenase 3) compose this group that cleaves, mainly native fibrillar collagen (types I, II, III, VII, VIII and X) ${ }^{11}$. The MMP-1 is important due to its wide action on these substrates (insoluble fibrillar collagen I, II and III) and is produced by smooth muscle cells, endothelial cells and keratinocytes ${ }^{12,13}$. The MMP- 8 is expressed by neutrophils, in particular, and is stored in your granules.

\section{Gelatinases}

Gelatinases act especially on already degraded fragments by collagenases, as type IV collagen, fibronectin, laminin, proteoglycans and elastin. The gelatinases comprises the MMP-2, expressed in vascular cells, and MMP-9 secreted in macrophages, polymorphonuclear cells, osteoblasts, fibroblasts and vascular cells ${ }^{2}$. The production of MMP-9 is more reduced compared to the expression of MMP-2, because it is produced by epithelial and 
Table 1: Metalloproteinases Diversity

\begin{tabular}{|c|c|c|c|c|}
\hline Group & MMP & $\begin{array}{c}\text { MW (kDa) } \\
\text { Latent/Active }\end{array}$ & Substrate & Other nomenclature \\
\hline \multirow{3}{*}{ Collagenases } & 1 & $52 / 42$ & $\begin{array}{l}\text { Collagenous I, II, III, VII, VIII, X, XI, } \\
\text { MMP-2, -9, -12 }\end{array}$ & $\begin{array}{l}\text { Interstitial collagenase, CL-1, CLG1, } \\
\text { fibroblastic collagenase }\end{array}$ \\
\hline & 8 & $85 / 64$ & $\begin{array}{l}\text { Collagenous I, II, III, V, VII, VIII, X, } \\
\text { fibronectin }\end{array}$ & $\begin{array}{c}\text { Neutrophilic collagenagese collagenase } \\
2 \text {, collagenase PMNL }\end{array}$ \\
\hline & 13 & $52 / 42$ & Collagenous I, II, III, V & Collagenase 3 \\
\hline \multirow{2}{*}{ Gelatinases } & 2 & $72 / 66$ & $\begin{array}{l}\text { Collagenous I, IV, V, VI, VII, X, XI, XIV, } \\
\text { elastin, fibronectin, MMP-2, -13 }\end{array}$ & $\begin{array}{l}\text { Gelatinase A, collagenase IV } \\
\text { or type } 4 \mathrm{~A} \text {, gelatinase } 72 \mathrm{kDa}\end{array}$ \\
\hline & 9 & $92 / 84$ & $\begin{array}{l}\text { Collagenous IV, V, VII, X, XII, XIV, elastin, } \\
\text { fibronectin }\end{array}$ & $\begin{array}{c}\text { Gelatinase B, collagenase IV, gelatinase } \\
\text { 92kDa, gelatinase PMNL }\end{array}$ \\
\hline \multirow{3}{*}{ Stromelysins } & 3 & $57 / 45$ & $\begin{array}{l}\text { Collagenous III, IV, IX, X, PLP, elastin, } \\
\text { fibronectin, laminin, MMP-1, -7, -8, -9, -13 }\end{array}$ & Stromelysin 1, proteoglicanase \\
\hline & 10 & $54 / 44$ & $\begin{array}{l}\text { Collagenous III, IV, V, elastin, } \\
\text { fibronectin, MMP-1, -8 }\end{array}$ & Stromelysin 2 \\
\hline & 11 & $64 / 46$ & & Stromelysin 3 \\
\hline \multirow[t]{2}{*}{ Matrilysins } & 7 & $28 / 19$ & $\begin{array}{l}\text { Collagenous IV, X, elastin, } \\
\text { fibronectin, laminin }\end{array}$ & Matrilysin 1 \\
\hline & 26 & $30 / 19$ & & Matrilysin 2 \\
\hline \multirow{6}{*}{$\begin{array}{l}\text { Membrane } \\
\text { Type }\end{array}$} & 14 & $66 / 54$ & $\begin{array}{l}\text { Collagenous I, II, III, fibronectin, } \\
\text { vitronectin, laminin, , MMP-2, -13 }\end{array}$ & MT1-MMP \\
\hline & 15 & $72 / 60$ & fibronectin, laminin, MMP-2 & MT2-MMP \\
\hline & 16 & $64 / 53$ & MMP-2 & MT3-MMP \\
\hline & 17 & $57 / 53$ & & MT4-MMP \\
\hline & 24 & $64 / 58$ & & MT5-MMP, MT21-MMP \\
\hline & 25 & $57 / 47$ & & MT6-MMP \\
\hline \multirow{5}{*}{ Others } & 28 & $48 / 58$ & & Epilisin \\
\hline & 12 & $52 / 22$ & $\begin{array}{c}\text { Collagenous IV, elastin, fibronectin, } \\
\text { vitronectin, laminin }\end{array}$ & Metalloelastase, macrophagous elastase \\
\hline & 19 & $54 / 45$ & & MMP-18, RASI-1 \\
\hline & 20 & $54 / 22$ & & Enamelisin \\
\hline & $18,21,23,27$ & unknown & unknown & unknown \\
\hline
\end{tabular}

Matrix metalloproteinases (MMP) classified in groups, attributed number, molecular weight, substrate and others denominations. MW: molecular weight. The MMP-4, 5,6 and 22 are not mentioned because were determined as identical to others ones ${ }^{7}$

eosinophil cells and stored in neutrophil granules. Therefore, high levels of MMP-9 can be found in inflammatory processes ${ }^{11}$.

\section{Stromelysins}

Stromelysins are expressed by stromal cells (chondrocytes, macrophages, fibroblasts, endothelial cells) and smooth muscle cells. They degrade the ECM fragmenting type III and IV collagens and proteoglycans (for example., laminin, fibronectin, aggrecan). The stromelysins consist of MMP-3 (stromelysin-1), MMP-10 (stromelysin-2) and MMP-11 (stromelysin-3). These MMP present similar performance features, but the MMP-3 are more efficient and can activate others MMP who are still in a pro-enzyme state ${ }^{2}$.

\section{Matrilysins}

The matrilysins, as the name itself implies, performs the lysis of the matrix (ECM) by degradation of versican, as well as elastin, fibronectin, collagen type IV and other fiber type. In this group, the MMP-7 (matrilysin-1) is expressed by glandular epithelial cells and, monocytes, intestinal and endothelial cells. The MMP26 (matrilysin-2) is produced during the process of differentiation of monocytes ${ }^{2}$.

\section{Membrane Metalloproteinases}

The membrane metalloproteinases (Membrane type-matrix metalloproteinases; MMP-MT) are usually expressed by neoplastic cells, but they are also produced by neuroglia cells and leukocytes, getting connected to the outer membrane of these cells. Peculiarly, these enzymes are not secreted in the pro-enzyme form, thus, they are first submitted to the activation cascade within the cell, and then to act in the extracellular matrix, after being secreted outside the cell. The MT-MMP disintegrates collagen types I, II and III, and they can activate other MMP ${ }^{11}$. Form this group the MMP-14 to 17,24 and $25^{2}$.

\section{Others Metalloproteinases}

Consist of other metalloproteinases, MMP-12 (expressed in macrophages) for example degrade elastin and other proteins of the matrix. In this group are also the MMP-19, 20 and 28.

\section{ATHEROSCLEROSIS MECHANISMS AND FACTORS RELATED TO ATHEROGENESIS}

Atherosclerosis is a multifactorial disease that evolves from arterial endothelial damage ${ }^{1,12-15}$. Several factors working in the 
cause of endothelium lesion, like dyslipidaemias, protein glycation products in diabetes, tobacco chemicals compounds and other infections. Physical intervenient factors as hypertension and blood gouging forces also cause endothelial injury and deformation ${ }^{1,16}$.

Lipid metabolic disturbances (dyslipidaemias), in the presence of endothelial injury with increased vascular permeability allows penetration of low density lipoproteins (LDL), which once oxidized (LDLox) trigger the recruitment of pro-inflammatory cells (e.g. monocytes) with action of cellular adhesion molecules (CAM) and other mediators, leading to activation of monocytes and its transformation into foam cells by absorption of LDLox $^{15,17,18}$. Then, other cells are drawn (e.g., lymphocytes); there is an increase of cell proliferation (e.g. smooth muscle cells $\mathrm{SMC}$ ) and release of metalloproteinases that degrade the fibers in the ECM, facilitating cellular diapedesis ${ }^{15,17-19}$.

The collagenase expression by macrophages in the intima and the inhibition of the collagenous synthesis come to be fragile the endothelium through the elasticity losing, resulting in dilatation and expansion of atheroma (stenosis). In the same time, the T lymphocytes, among others cells, increases the pro-coagulant factors production and, when the atheroma spurs, inflammatory signalling factors provoke the thrombosis, which causes the acute complications of atherosclerosis (ischaemic): acute coronary syndrome, myocardial infarct and cerebral vascular accident ${ }^{15,17-19}$.

\section{The action of metalloproteinases in atherosclerotic processes}

The metalloproteinases have important role in triggering and along the development of inflammatory process, particularly in the vascular ones, though the exact mechanism is not yet fully known (Figures 1 and 2). In atherosclerosis, the action of metalloproteinases begins after the initiation of the inflammatory process for the formation of atherosclerotic plaque, when cells with inflammatory action (in particular monocytes and foam cells) are already within the intima. These cells begin to release cytokines and super oxidases that activate metalloproteinases, including collagenases that affect the integrity of the plaque. Among the main metalloproteinases, which mediate this process of degradation, the MMP-1, 2, 3, 9, 12, and 13 have a relevant role, in conjunction with the matrix desintegrins and metalloproteinases (ADAM-1, ADAM-8, ADAM-15) and tissue inhibitors of matrix metalloproteinases (TIMP) ${ }^{20}$.

The MMP expression and activation in atherosclerotic plaque promote the atherosclerotic process through plaque instability and platelet aggregation. Alteration/activation of MMP contributes to the progress of diseases such as atherosclerosis, pulmonary emphysema, vascular aneurysm, cardiac insufficient flux, as well as tumor growth, invasion and metastasis ${ }^{16}$. The balance between MMP and TIMP is essential for maintaining integrity of the vascular system ${ }^{5,19}$, therefore, any alteration or disruption of the ECM contributes to the atherosclerosis advancement and plaque instability ${ }^{21}$. The elevation of plasma concentration of C-reactive protein (CRP) is a relevant determinant of atherosclerotic plaque instability and is correlated to local collagenases (MMP-8 and 9) and increased synthesis of integrin (CD40) for direct or indirect action of immune cells and can still occur with association of virulent factors from specific micro biota (e.g. Cytomegalovirus) ${ }^{19,22}$. The action of MMP in atherosclerosis is due to various biological processes which are related to the disease itself and partly controlled by these enzymes, but presents divergent consequences on the

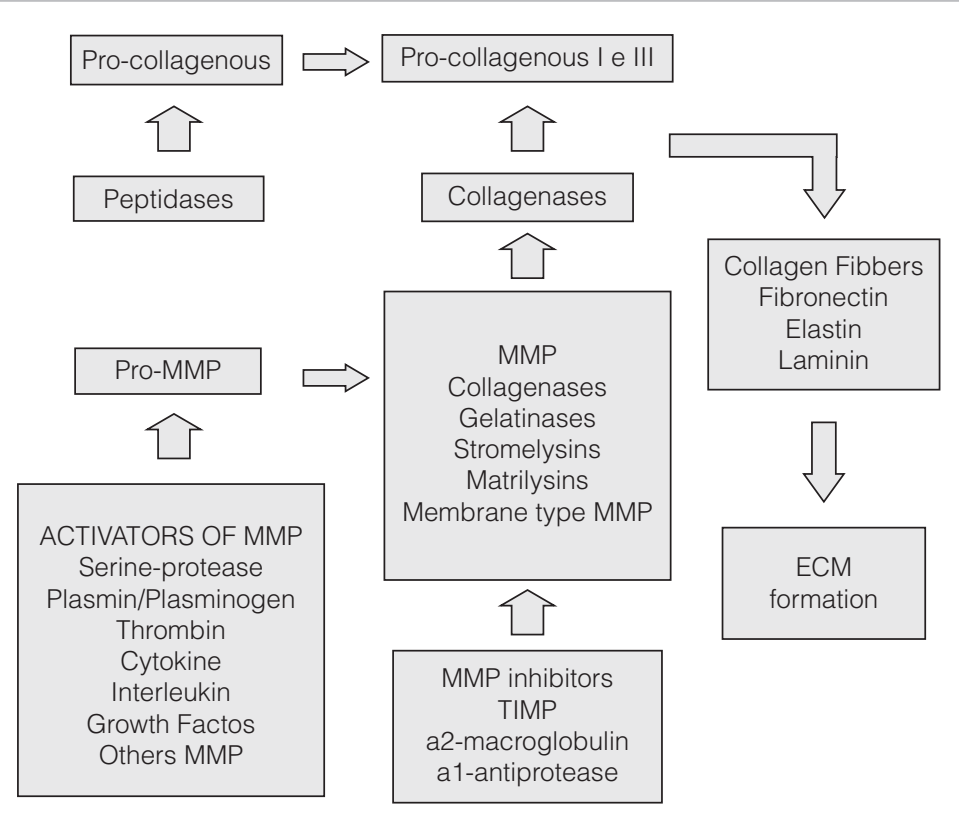

MMP: metalloproteinase; TIMP: tissue inhibitors of metalloproteinases.

Figure 1: Metalloproteinases action diagram: interaction among the metalloproteinase and substrates along the formation of extracellular matrix 


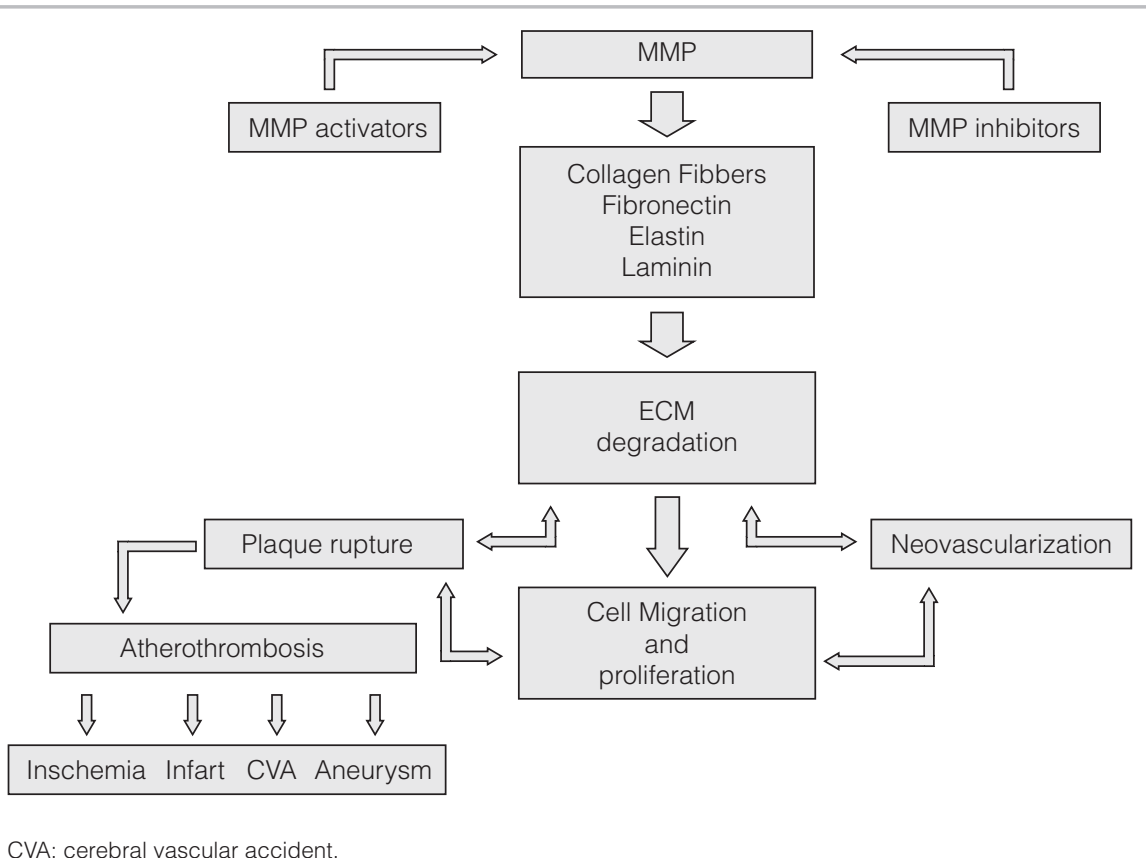

MMP: metalloproteinases; CVA: cerebral vascular accident.

Figure 2: Metalloproteinases regulation diagram: interaction among the metalloproteinase and regulators (activators and inhibitors) along the degradation of extracellular matrix in the atherogenic process and vascularization

development of the injury and on the stability of the fibrous cap. The induction and activation of MMP (MMP-1, 2 and 14-MT1MMP) facilitate the invasion of the plate for smooth muscle cells and fibroblasts. Migration and proliferation of these cells are important for the hyperplasic development of intima, in the same way that the MMP allow infiltration of monocytes in the vascular wall, as well as determines the increase of certain MMP expression (for example, MMP-12) which leads to infiltration of macrophages, rupture of the internal elastic lamina and the acceleration of the atherosclerotic process ${ }^{13,23,24}$.

The MMP-1 is one of the most prominent MMP as an indicator of cardiovascular risk. Is induced by hepatocyte growth factor (HGF), thrombin, vascular endothelial growth factor (VEGF) and tumor necrosis factor alpha (TNF- $\alpha$ ) and mediated and regulated by the early growth response- 1 transcription factor (Erg-1) and inhibitors of TIMP-1 and 2. The MMP-1 act on ECM proteolysis (commonly degrading Collagen fibers) and facilitate the entrance of cells in the tissue by activation of MMP-2, by inhibition of TIMP-2 followed by activation of MMP-9, 3, 12, 13, 15, and ADAMT-1, allowing the movement of cells in the tissue and increasing the extent of degradation and the invasion of the matrix. The MMP-1 is also an indicator of the risk of rupture of calcified and non-calcified plates, correlated to MMP-9, CRP, serum triglyceride levels and body mass index ${ }^{16}$.

The MMP- 1 and 3 and TIMP- 1 act decisively in cardiovascular diseases, regardless of the severity degree of arterial disease and presenting positive correlation between their concentrations ${ }^{21}$. Circulating levels of MMP-1, 2, 3 and 9 are useful indicators for aortic disease and myocardial ischemia using rapid clinical trials along with imaging tests. Patients with acute myocardial ischemia, indicated by acute aortic dissection, reveal high levels of MMP-2, 3 and 9 in serum, whereas healthy controls ones show low levels of MMP- $1^{25}$. The activity of MMP-2 and 9, among others, is crucial to the neovascularization atheroma. These processes are induced by inflammatory pro-angiogenic stimuli and seem to be necessary for the development of plaque and are associated with the vulnerability of advanced lesion ${ }^{25}$.

The MMP-7 acts on the proteoglycans, especially versican and is the main type of MMP present on the walls of blood vessels. The MMP-7 was identified in versican-rich sites in atherosclerotic lesions and can degrade the proteoglycan more efficiently when compared to other MMP, as, for example, MMP- $3^{21}$. Otherwise, versican is not a proteoglycan consisting of heparan sulfate, and a study performed with uterine tissue shows the association between MMP-7 and this glycosaminoglycan, proposing that heparan sulfate acts like link site for MMP- $7^{21}$. However, some authors ${ }^{26}$ consider that MMP-7 does not have any effect on the growth or stability of plate.

The MMP- 8 presents premature role in atherogenic process with gradual elevation levels in serum along the progress of the disease. When associated with atherosclerosis and other cardiovascular events, the MMP-8 shows high concentrations ${ }^{24}$, promoting atherosclerosis aggravation and the plaque rupture ${ }^{27}$. The inactivation of MMP-8 in knockout mice (MMP8 -/-/apoE -/-), decreases the extent of atherosclerosis by reducing the amount of macrophages and increasing of collagen fibers in the atherosclerotic lesion, similar to what occurs by inhibition of MMP-1, 3, 13 and 14. Those same mice exhibit low levels of angiotensin-2 (Ang II) - MMP-8 cleaves the Ang II which, in its turn, would induce the expression of adhesion molecules such as VCAM-1 - low 
blood pressure, lowered expression of cell adhesion molecules-1 (VCAM-1) and reduced recruitment of vascular leukocyte ${ }^{12,13,28-30}$. The functional analysis of the gene for MMP-8 in population of patients with carotid atherosclerotic disease (CAD) (Bruneck Study, Italy, 1990) shows that there is association between the gene variation and the extent of atherosclerosis, as well as the plasma level of VCAM-1 and the progression of atherosclerosis ${ }^{24}$.

The MMP-9 is essential for the matrix degradation in the atheroma and his expression is far superior in unstable plaques than in stable ones, mainly around the necrotic core, where there are concentrations of foam cells and macrophages ${ }^{15,18}$. Serum levels of MMP-9 are associated with increased risk of coronary disease. The serum of patients with systolic hypertension and/or arterial atherosclerosis presents increased levels of MMP-9 and 2 when compared to those in healthy subjects ${ }^{25,28}$. At the same time, several authors assert that the MMP-9 is predictive factor of cardiovascular disease caused by atherosclerosis, including myocardial infarction, in association with the MMP-1 and 2, TIMP-1 and 2. Although, some other authors ${ }^{25,28,31}$ are unable to determine any correlation between circulating levels of MMP-9 and the obstructive coronary disease or death by cardiovascular disease, other ${ }^{32}$ studies establish that the increasing levels of MMP-9 circulating are associated with high prevalence of carotidal stenosis, together with TIMP-1 in patients of the Framingham Offspring Study (USA) after duplex carotidal ultrasonography. Also is observed the increase of MMP-9 in coronary plaques in patients with unstable angina if compare to that of stable ones and it is related to vascular remodeling post-infarct ${ }^{32}$.

The MMP-9 has critical participation in rupture of atherosclerotic plaque and exposure of necrotic core (disruption), but in certain levels MMP-2 and 9 have protective role because they act on vascular remodeling, while the MMP-7, 8, 12 and 13 act as plaque destabilizing factors ${ }^{21,26}$. However, these data are in conflict because some authors ${ }^{33}$ also affirm that the MMP-1 and 3 cause the worsening injury while other authors ${ }^{21,26}$ insist that they have protective role. In fact, the action of MMP-9 is protective at determinate concentration and at certain stage of progress of atheroma plaque, but at a critical moment (serious injury), the concentration of MMP-9 in the tissue increases and promotes the rupture of the plate ${ }^{34}$. Atherosclerotic injury induces local production and activation of MMP-9 which, in its time, triggers the rupture of vulnerable plaques ${ }^{32}$. This MMP also modifies the local level of interleukin-8 (IL-8), stimulating the cell infiltration and necrotic core growth. These events increase the chances of thrombotic ischemia by reducing the mechanical strength of the fibrous cap ${ }^{35}$. This behavior of MMP-9, in particular, is evidenced by the fact that the plasma levels of MMP-9, in cohorts with cardiovascular risk associated with atherosclerosis, be less $(33.5 \pm 17.6 \mathrm{ng} / \mathrm{mL}, \mathrm{p}<0.001)$ than in healthy individuals $(82.4 \pm 40.6 \mathrm{ng} / \mathrm{mL}, \mathrm{p}<0.001)$ regardless of age. This performance occurs because probably this MMP is involved in preservation of arterial conditions and in the maintenance of vascular health. Serum levels of metalloproteinases are lower in sick rats than in normal ones and precede the lesion formation, in particular in cases of atherosclerosis, and in hyperinsulinemia and insulin resistance cases as well. In this way, the reduced levels of MMP lead to increased accumulation of extracellular matrix proteins and then incite premature development of vascular injury ${ }^{36}$. These data corroborate with the assertion ${ }^{37}$ that levels of certain MMP (MMP-1, 2, 3, 7, 8 and 9) and TIMP (TIMP 1, 2 and 4) are associated with structural changes and remodeling of carotid wall and correlated with the ruptured plaque in elderly people. By the way, these data also are in line with the fact that the MMP-1, 3, 7, 8 and 13 stimulate the degradation of fibrous cap and the induction of plaque rupture ${ }^{21,34}$. The thrombosis and plaque spurs are the main cause of Acute Coronary Syndrome and myocardial infarction. The MMP are involved in these processes and promote instability of atherosclerotic plaque and its vulnerability ${ }^{21}$.

Even on the role of MMP-9, there is evidence that participates in the atherosclerotic inflammatory process, arterial lesions and coronary heart diseases, as well as other diseases such as arthritis, asthma and cancer, showing a considerable increase in its concentration $^{18}$.

Among the other metalloproteinases, the MMP-10, 12 and 15 also participate in the morphogenesis, tissue remodeling, and the advancement of instability of atherosclerotic plaque, causing rupture, followed by vascular thrombosis and coagulation cascade activation $^{38}$

\section{Others activities of metalloproteinases}

The metalloproteinases are also expressed by some cells outside of the extracellular matrix of vascular tunic, such as endothelial cells, mesenchymal cells, eosinophils and other leukocytes. Obviously, the action of the MMP focuses on disintegrating the extracellular matrix fibers, collagen in particular, especially in cases of several inflammatory diseases, such as acute coronary syndromes, myocardial infarction, cardiomyopathy, aneurysms, cancer, arthritis, chronic inflammatory diseases and atherosclerosis. But they also act in non-pathological processes such as organ development, restenosis, vascular remodeling and healing. In the case of atherosclerosis, the MMP assist recruitment induction and facilitating the migration of cells, including macrophages and smooth muscle cells, and so more critical, the MMP promote instability of atherosclerotic plaque, leading to rupture of the fibrous $\operatorname{cap}^{12,13,18,39,40}$.

Some authors refer to the peculiar ways of the metalloproteinases action in inflammation and blood vessel injuries, as, for example, the ability of MMP-12 in cleave fibrinogen ${ }^{38}$ reducing the progression of atherosclerosis and protecting against myocardial infarction. On the other hand $\mathrm{d}^{41}$, the increasing in levels of circulating angiotensin, while there is reduction in levels of angiostatin and plasminogen (modulated by renina, angiotensin-converting enzyme 2 [ACE2], reactive oxygen species [ROS], gene transcription factors [e.g. NF-kB]) is associated with the MMP-9 increase 
expression by endothelial cells, macrophages and by smooth muscle cells of blood vessels, promoting the elevation of the blood pressure and growth of atherosclerotic lesions. At the same time ${ }^{42}$, the improved expression of MMP-2 and 9 provokes the development of hypertension, caused by hypertrophy of arterial wall with excessive deposition of collagen and elastin, as well as increases the oxidative stress ${ }^{43}$ and vascular contraction along the vascular remodeling. This oxidative stress launches a sequence of events that are responsible for the endothelium damage, which start the atherosclerotic lesion in the vascular wall and induce the formation of oxidized-LDL (ox-LDL). The endothelium dysfunction is related to $\mathrm{MMP}^{44}$ (in particular the MMP-2 and 9) through the action of pro-inflammatory molecules (e.g. C-reactive protein [CRP], Interleukin-6 [IL6]; monocytes chemo-attractive protein-1 [MCP-1], tumor necrosis factor-alpha [TNF- $\alpha$ ]), causing oxidative stress by release of oxidative molecules (e.g. nicotinamide adenine dinucleotide phosphate-oxidase [NADPH] and superoxide $\left[\mathrm{O}_{2}^{-}\right]$) and promoting the development of the atherosclerotic lesion.

However, the action of metalloproteinases is not restricted to healing tissue remodeling and inflammatory process, taking crucial role in maintaining the structure and function of tissues so that they do not suffer structural collapse or organic disorder ${ }^{45}$.

\section{FINAL CONSIDERATIONS}

In resume, the MMP are involved in vascular remodelling and cellular diapedesis ${ }^{23,26}$ However, in the early stages of atherosclerotic disease it usually have low levels of circulating concentration, with consequent disease progression ${ }^{35,37}$. In more advanced stages of cardiovascular disease, from certain concentrations, the MMP act maximizing inflammatory effects, increased recruitment of inflammatory cells, smooth muscle cells migration and the swelling of the atheroma with subsequent plaque instability ${ }^{18,21}$, promoting, thus, increasing the atherosclerotic lesion. As a result, low or high concentrations of MMP, particularly of MMP-2 and 9 in later stages of atherosclerotic disease may reflect a greater degree of vascular inflammation, which, in terms of associated diagnoses, allow the use of serum and plasma values as predictive parameters of clinical extension of arterial inflammation due to atherosclerosis ${ }^{18,23}$.

\section{REFERENCES}

1. Ferraz MLF. Avaliação morfológica da aterosclerose em aortas de pacientes autopsiados. Tese (Doutorado) - Universidade Federal do Triângulo Mineiro, Uberaba, 2008

2. Borges LF, Touat Z, Leclercq A, Zen AA, Jondeau G, Franc B, et al. Tissue diffusion and retention of metalloproteinases in ascending aortic aneurysms and dissections. Hum Pathol. 2009;40(3):306-13. http://dx.doi.org/10.1016/j.humpath.2008.08.002

3. Nagase H, Woessner JF Jr. Matrix metalloproteinases. J Biol Chem. 1999;274(31):21491-4 http://dx.doi.org/10.1074/jbc.274.31.21491

4. Opdenakker G, Van den Steen PE, Van Damme J. Gelatinase B: a tuner and amplifier of immune functions. Trends Immunol. 2001;22(10):571-9 http://dx.doi.org/10.1016/S1471-4906(01)02023-3

5. Galis ZS, Khatri JJ. Matrix metalloproteinases in vascular remodeling and atherogenesis: the good, the bad, and the ugly. Circ Res. 2002;90(3):251-62.

6. Visse R, Nagase H. Matrix metalloproteinases and tissue inhibitors of metalloproteinases: structure, function, and biochemistry. Circ Res. 2003;92(8):827-39. http://dx.doi.org/10.1161/01.RES.0000070112.80711.3D

7. Klein T, Bischoff R. Physiology and pathophysiology of matrix metalloproteinases. Amino Acids. 2011:41(2):271-90. http://dx.doi.org/10.1007/s00726-010-0689-x

8. Sang QX. Complex role of matrix metalloproteinases in angiogenesis. Cell Res. 1998;8(3):171-7. http://dx.doi.org/10.1038/cr.1998.17

9. Rutschow S, Li J, Schultheiss HP, Pauschinger M. Myocardial proteinases and matrix remodeling in inflammatory heart disease. Cardiovasc Res. 2006;69(3):646-56.

http://dx.doi.org/10.1016/j.cardiores.2005.12.009
10. VuTH, Werb Z. Matrix metalloproteinases: effectors of development and normal physiology. Genes Dev. 2000;14(17):2123-33. http://dx.doi.org/10.1101/gad.815400

11. Miyage SPH. Análise in vitro da expressão de proteínas da matriz extracelular (ECM) e de metaloproteinases de matriz (MMPs) em células- tronco da polpa dentária humana. Tese (Doutorado) Universidade de São Paulo, São Paulo, 2008.

12. Fang $C$, Wen $G$, Zhang L, Lin L, Moore A, Wu S, Ye S, Xiao Q. An important role of matrix metalloproteinase-8 in angiogenesis in vitro and in vivo. Cardiovasc Res. 2013;99(1):146-55 http://dx.doi.org/10.1093/cvr/cvt060

13. Xiao Q, Zhang F, Lin L, Fang C, Wen G, Tsai TN, et al. Functional role of Matrix Metalloproteinase-8 in Stem/Progenitor cell migration and their recruitment into atherosclerotic lesions. Circ Res. 2013;112:35-47.

http://dx.doi.org/10.1161/CIRCRESAHA.112.274019

14. Lima ES, Couto RD. Estrutura, metabolismo e funções fisiológicas da lipoproteína de alta densidade. J Bras Patol Med Lab. 2006;42(3):169-78

http://dx.doi.org/10.1590/S1676-24442006000300005

15. Galkina E, Ley K. Immune and inflammatory mechanisms of atherosclerosis. An Rev Immunol. 2009:27:165-97. http://dx.doi.org/10.1146/annurev.immunol.021908.132620

16. Siefert SA, Sarkar R. Matrix metalloproteinases in vascular physiology and disease. Vascular. 2012;20(4):210-6. http://dx.doi.org/10.1258/vasc.2011.201202

17. Torzewski M, Suriyaphol P, Paprotka K, Spath L, Ochsenhirt $\mathrm{V}$, Schmitt A, et al. Enzymatic modification of low-density lipoprotein in the arterial wall: a new role for plasmin and matrix metalloproteinases in atherogenesis. Arterioscler Thrombos Vasc Biol. 2004;24(11):2130-6

http://dx.doi.org/10.1161/01.ATV.0000144016.85221.66 
18. Kalela A. Factors affecting serum matrix metalloproteinase-9 with special reference to atherosclerosis. Thesis (Doctoral) - Medical School of the University of Tampere. 2002.

19. Libby P. Inflammation and atherosclerosis. Nature. 2002;420(6917):868-74 http://dx.doi.org/10.1038/nature01323

20. Inoue T, Kato T, Takayanagi K, Uchida T, Yaguchi I, Kamishirado $\mathrm{H}$, et al. Circulating matrix metalloproteinase- 1 and -3 in patients with and acute coronary syndrome. Am J Cardiol. 2003;92:1461-4 http://dx.doi.org/10.1016/j.amjcard.2003.08.061

21. Yu WH, Yu S, Meng Q, Brew K, Woessner JF Jr. TIMP-3 binds to sulfated glycosaminoglycans of the extracellular matrix. J Biol Chem. 2000;275(40):31226-32. http://dx.doi.org/10.1074/jbc.M000907200

22. Newby AC. Dual role of matrix metalloproteinases (matrixins) in intimal thickening and atherosclerotic plaque rupture. Physiol Rev. 2005;85(1):1-31. http://dx.doi.org/10.1152/physrev.00048.2003

23. Fonseca ALM. Metaloproteinases de matriz e incorporação de colesterol na lipoproteína de alta densidade (HDL) na doença carotídea. Tese (Doutorado) - Fundação Oswaldo Cruz, Salvador, 2012. p. 93.

24. Mallat Z. Inflammation, and atherosclerotic lesion growth matrix metalloproteinase-8 and the regulation of blood pressure, vascular. Circ Res. 2009; 105:827-9.

http://dx.doi.org/10.1161/CIRCRESAHA.109.208595

25. Karapanagiotidis GT, Antonitsis P, Charokopos N, Foroulis $\mathrm{CN}$, Anastasiadis K, Rouska E, et al. Serum levels of matrix metalloproteinases $-1,-2,-3$ and -9 in thoracic aortic diseases and acute myocardial ischemia. J Cardiothoracic Surg. 2009;4:59. http://dx.doi.org/10.1186/1749-8090-4-59

26. Jackson ZS, Dajnowiec D, Gotlieb AI, Langille BL. Partial off-loading of longitudinal tension induces arterial tortuosity. Arterioscler Thrombos Vasc Biol. 2005;25(5):957-62. http://dx.doi.org/10.1161/01.ATV.0000161277.46464.11

27. Sebastian L, Mach F, Montecucco F. Role of Matrix Metalloproteinase-8 in Atherosclerosis. Mediat Inflamm. 2013;(2013):1-6.

http://dx.doi.org/10.1155/2013/659282

28. Beaudeux JL, Giral P, Bruckert E, Foglietti MJ, Chapman MJ. Métalloprotéases matricielles et athérosclérose. Perspectives thérapeutiques. Ann Biol Clin. 2003;61(2):147-58.

29. Halpert I, Sires UI, Roby JD, Potter-Perigo S, Wight TN, Shapiro $\mathrm{SD}$, et al. Matrilysin is expressed by lipid-laden macrophages at sites of potential rupture in atherosclerotic lesions and localizes to areas of versican deposition, a proteoglycan substrate for the enzyme. Proc Natl Acad Sci U S A. 1996;93(18):9748-53. http://dx.doi.org/10.1073/pnas.93.18.9748

30. Djurić T, Zivković M, Stanković A, Kolaković A, Jekić D, Selaković V, Alavantić D. Plasma levels of matrix metalloproteinase-8 in patients with carotid atherosclerosis. J Clin Lab Anal. 2010;24(4):246-51. http://dx.doi.org/10.1002/jcla.20393

31. Wang KF, Huang PH, Chiang CH, Hsu CY, Leu HB, Chen JW, Lin SJ. Usefulness of plasma matrix metalloproteinase-9 level in predicting future coronary revascularization in patients after acute myocardial infarction. Coron Artery Dis. 2013;24(1):23-8. http://dx.doi.org/10.1097/MCA.0b013e32835aab4a
32. Lubos E, Schnabel R, Rupprecht HJ, Bickel C, Messow CM, Prigge $\mathrm{S}$, et al. Prognostic value of tissue inhibitor of metalloproteinase-1 for cardiovascular death among patients with cardiovascular disease: results from the AtheroGene Study. Eur Heart J. 2006;27(2):150-6.

http://dx.doi.org/10.1093/eurhearti/ehi582

33. Romero JR, Vasan RS, Beiser AS, Polak JF, Benjamin EJ, Wolf PA, et al. Association of carotid artery atherosclerosis with circulating biomarkers of extracellular matrix remodeling: the Framingham Offspring Study. J Stroke Cerebrovasc Dis. 2008;17(6):412-7. http://dx.doi.org/10.1016/j.jstrokecerebrovasdis.2008.06.002

34. Schwartz SM, Galis ZS, Rosenfeld ME, Falk E. Plaque rupture in humans and mice. Arterioscler Thrombos Vasc Biol. 2007;27:705-13. http://dx.doi.org/10.1161/01.ATV.0000261709.34878.20

35. Xin JIG, He-Song ZG, Yi G, Zhi-Bin Z, Bing-Shan TG, Fu-Kang LI. The expression of matrix metalloproteinases-9, transforming growth factor- $\beta 1$ and transforming growth factor- receptor in human atherosclerotic plaque and their relationship with plaque stability. Chin Med J. 2004;117(12):1825-9.

36. Wilson D, Massaeli H, Russell JC, Pierce GN, Zahradka P. Low matrix metalloproteinase levels precede vascular lesion formation in the JCR:LA-cp rat. Mol Cell Biochem. 2003;249(1-2):151-5. http://dx.doi.org/10.1023/A:1024747008288

37. Gaubatz JW, Ballantyne CM, Wasserman BA, Max HE, Chambless LE, Boerwinkle E, Hoogeveen RC. Association of circulating matrix metalloproteinases with carotid artery characteristics: the atherosclerosis risk in Communities Carotid MRI Study. Arterioscler Thrombos Vasc Biol. 2010;30(5):1034-42. http://dx.doi.org/10.1161/ATVBAHA.109.195370

38. Motterle A, Xiao Q, Kiechl S, Pender SL, Morris GE, Willeit J, Caulfield MJ, Ye S. Influence of matrix metalloproteinase-12 on fibrinogen level. Atherosclerosis. 2012;220(2):351-4. http://dx.doi.org/10.1016/j.atherosclerosis.2011.11.003

39. Libby, P. Collagenases and cracks in the plaque. J Clin Invest. 2013;123(8):3201-3. http://dx.doi.org/10.1172/JCl67526

40. Siasos G, Tousoulis D, Kioufis S, Oikonomou E, Siasou Z, Limperi M, Papavassiliou Ag, Stefanadis C. Inflammatory mechanisms in atherosclerosis: the impact of matrix metalloproteinases. Curr Top Med Chem. 2012;12(10):1132-48. http://dx.doi.org/10.2174/1568026611208011132

41. Sahara M, Ikutomi M, Morita T, Minami $Y$, Nakajima T, Hirata $Y$, et al. Deletion of Angiotensin-converting Enzyme 2 Promotes the Development of Atherosclerosis and Arterial Neointima Formation. Cardiovasc Res. 2014;101(2):236-46. http://dx.doi.org/10.1093/cvr/cvt245.

42. Guimarães DA, Rizzi E, Ceron CS, Martins-Oliveira A, Gerlach RF, Santos JET. Inibição de metaloproteinases da matriz extracelular: uma possível estratégia terapêutica na hipertensão arterial? Rev Bras Hipertens. 2010;17(14):226-30.

43. Silva DC, Gerchiaro G. Relações patofisiológicas entre estresse oxidativo e arteriosclerose. Qim Nova. 2011;34(2):300-5 http://dx.doi.org/10.1590/S0100-40422011000200024

44. Araújo RVS, Silva FO, Melo-Júnior MR; Porto AL. Metaloproteinases: aspectos fisiopatológicos sistêmicos e sua importância na cicatrização. Rev Ciênc Méd Biol. 2011;10(1):82-8.

45. Silva JM, Saldanha C. Endotélio Arterial e Aterotrombogénese II: disfunção endotelial e desenvolvimento das lesões aterotrombóticas. Rev Port Cardiol. 2006;25(12)1159-86. 